\title{
Two novel linkage SNPs of VLDLR gene intron 11 are associated with laying traits in two quail populations
}

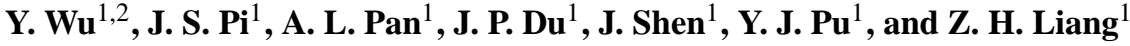 \\ ${ }^{1}$ Institute of Animal Science and Veterinary Medicine, Hubei Academy of Agricultural Sciences, \\ Wuhan 430064, China \\ ${ }^{2}$ Hubei Key Laboratory of Animal Embryo and Molecular Breeding, Wuhan 430064, China
}

Correspondence to: J. P. Du (youngwuyan@163.com)

Received: 10 March 2014 - Accepted: 24 September 2014 - Published: 4 March 2015

\begin{abstract}
The very low density lipoprotein receptor (VLDLR) is an important multifunctional receptor and plays a key role in chicken reproduction. This study is designed to investigate the effect of variants in the VLDLR gene on quail laying traits. Two quail populations were studied - yellow feather quail and chestnut feather quail; 384 individuals per breed were used. The laying traits (the weight of the first egg, the age of the first egg, egg weight, the weight of 20 -week-old and the egg number of 20 -week-old) were measured and recorded. The polymerase chain reaction-restriction fragment length polymorphism (PCR-RFLP) method was developed to genotype those individuals. The results showed two novel polymorphisms, i.e. two linkage variations in intron 11 of the VLDLR gene (363T $>C$ and 392C $>$ T). They are associated with the weight of the first egg, the age of the first egg and egg number of 20-week-old in yellow feather and chestnut feather quail. The two variations in intron 11 of VLDLR may be linked with potential major loci or genes affecting some laying traits.
\end{abstract}

\section{Introduction}

The very low density lipoprotein receptor (VLDLR) is a key component in mediating the absorption of yolk protein precursors (very low density lipoprotein and vitellogenin) from plasma. It is a $95 \mathrm{kDa}$ plasma membrane protein which is located on the sex chromosome Z (Barber et al., 1991; Bujo et al., 1994). VLDLR is also referred to as the oocyte vitellogenesis receptor (OVR) or vitellogenin receptor (VTGR) (Nimpf and Schneider, 1991). VLDLR mediates a key step in the reproductive effort of hens; this is confirmed by a chicken strain which carries a single mutation at the VLDLR locus and cannot lay eggs and which also displays female sterility (Nimpf et al., 1989). The single mutation of VLDLR is caused by a single base exchange which leads to the replacement of a cysteine residue in the extracellular domain of VLDLR with a serine (Bujo et al., 1995, 1996). Some reports have shown that VLDLR plays a key role in chicken reproduction, including the development of oocytes and yolk lipoprotein deposition (Barber et al., 1991; Shen et al., 1993). VLDLR has co-evolved in oviparous and viviparous animals to support ligand transport inside the cell and to sustain the reproductive effort of oviparous species (Schneider et al., 1999; Schneider and Nimpf, 2003). A recent study of zebra finches suggests that VLDLR mRNA expression is pivotal for reproduction in oviparous species (Han et al., 2009); a study of ducks suggests that ducks' and chickens' VLDLR genes probably perform a similar function in the development of growing oocytes and deposition of yolk lipoprotein and that VLDLR could be a candidate gene for egg performance in poultry (Wang et al., 2011). The aim of this study was to detect polymorphisms of the VLDLR gene in two quail populations (the yellow feather and chestnut feather quail, breeding in Hubei Province, China), to investigate their associations with laying traits and to initiate the possibility of single-nucleotide polymorphisms (SNPs) in the VLDLR gene being used as molecular genetic markers for laying traits. 
Table 1. Primer sequence, product size and annealing temperatures used in analyses of quail VLDLR gene.

\begin{tabular}{lcllc}
\hline $\begin{array}{l}\text { Primer } \\
\text { name }\end{array}$ & $\begin{array}{l}\text { Product } \\
\text { size, } \mathrm{bp}\end{array}$ & Primer sequence (5'-3') & $\begin{array}{l}\text { Amplified } \\
\text { region }\end{array}$ & $\begin{array}{c}\text { Annealing } \\
\text { temperature X, }{ }^{\circ} \mathrm{C}\end{array}$ \\
\hline P1 & 325 & $\begin{array}{l}\text { F: CAGTAGTGGGCAGTGTATT } \\
\text { R: ATCACTTCCATCTTTGCA }\end{array}$ & Exon 5 & 55 \\
\hline P2 & 233 & $\begin{array}{l}\text { F: GAGCAGGCAGTGCAATGGT } \\
\text { R: CAGTCTCCGTGATGGTTAC }\end{array}$ & Intron 6 & 58 \\
\hline P3 & 493 & $\begin{array}{l}\text { F: CCTCTATTGATACCCGTGAT } \\
\text { R: TTAGGCCATTGGATTTCTGT }\end{array}$ & Intron 11 & 56 \\
\hline P4 & 333 & $\begin{array}{l}\text { F: CCGTCTGTATTGGCTTGATT } \\
\text { R: GAGGTTGTTTACTAGGGTGA }\end{array}$ & Intron 13 & 58 \\
\hline
\end{tabular}

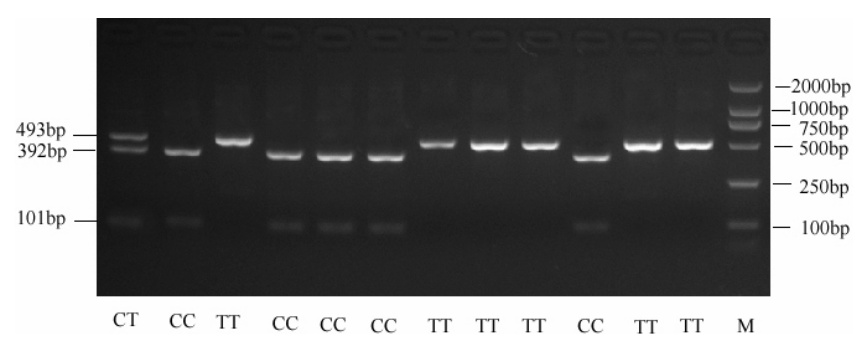

Figure 1. PCR-RFLP band pattern on a $3 \%$ non-denaturing polyacrylamide gel. The TT (also named $\mathrm{C}_{1} \mathrm{C}_{1} \mathrm{~T}_{2} \mathrm{~T}_{2}$ ) genotype has one slow-running band; the $\mathrm{CC}$ (also named $\mathrm{T}_{1} \mathrm{~T}_{1} \mathrm{C}_{2} \mathrm{C}_{2}$ ) genotype has one fast-running band; and the $\mathrm{CT}$ (also named $\mathrm{C}_{1} \mathrm{~T}_{1} \mathrm{C}_{2} \mathrm{~T}_{2}$ ) genotype has two bands, one of which is slow-running and the other fast-running.

\section{Material and methods}

\subsection{Sample collection}

Two quail populations (the yellow feather quail (384) and the chestnut feather quail (384)) were used in this study for initial SNP discovery. The two populations have different laying performance: the yellow feather quail has higher egg weight and the chestnut feather quail has higher egg number. All birds were raised in cages and fed commercial cornsoybean diets that met the quails' requirement. Blood samples and phenotypic data on laying traits (the weight of first egg, the age of first egg, egg weight, the weight of 20-weekold and the egg number of 20 -week-old) were collected from the 768 individuals. Genomic DNA was obtained by phenol and chloroform $(1: 1)$ extraction and stored at $-20^{\circ} \mathrm{C}$.

\subsubsection{Primer design and PCR amplification}

According to the chicken VLDLR gene sequence (GenBank accession no. NC_006127), four pairs of primers (Table 1) were designed to amplify and detect the SNPs for the quail VLDLR gene exon 5, intron 6, intron 11 and intron 13 regions. The polymerase chain reaction (PCR) was performed by mixing $40 \mathrm{ng}$ of genomic DNA, $0.5 \mathrm{pmol}$ of each of forward and reverse primer, $1.5 \mu \mathrm{L}$ of $10 \times$ buffer, $1.5 \mathrm{mM}$ of $\mathrm{MgCl}_{2}, 0.25 \mathrm{mM}$ of deoxyribonucleotide triphosphate, and 1.5 U of Taq DNA polymerase (Fermentas, Shenzhen, China) in a $15 \mu \mathrm{L}$ volume, and was run on an Eppendorf Mastercycler gradient (Eppendorf AG, Hamburg, Germany) according to the following method: $95^{\circ} \mathrm{C}$ for $5 \mathrm{~min} ; 35$ cycles of $94^{\circ} \mathrm{C}$ for $30 \mathrm{~s}$, annealing of $X^{\circ} \mathrm{C}$ for $35 \mathrm{~s}$, and $72^{\circ} \mathrm{C}$ for $45 \mathrm{~s}$; and final extension step at $72^{\circ} \mathrm{C}$ for $10 \mathrm{~min}$.

\subsubsection{SNP identification and genotyping by PCR-RFLP}

Genomic DNA from two populations of quails was used as a template for amplification by four pairs of primers (exon 5, intron 6,11 and 13) and the sequences were aligned to search for base variations.

The polymorphisms in quail VLDLR gene exon 5, intron 6,11 and 13 were analysed using the polymerase chain reaction-restriction fragment length polymorphism (PCRRFLP) method, which was performed by mixing $8 \mu \mathrm{L}$ of PCR product, $10 \mathrm{U}$ of the restriction enzyme FatI (Fermentas, Shenzhen, China) and $1 \mu \mathrm{L}$ of the corresponding $10 \times$ reaction buffer and then incubating overnight at $37^{\circ} \mathrm{C}$ for $12 \mathrm{~h}$. Then the products were electrophoresed on $3 \%$ agarose gels and stained with ethidium bromide for visualization of products. Three PCR fragments for each locus from different PCR-RFLP patterns in different populations were subcloned to the $\boldsymbol{T}$ vector (Takara, Dalian, China). Sequencing reactions were performed with BigDye Terminator chemistry and resolved on an ABI PRISM 3730 DNA (Applied Biosystems, Foster City, CA, USA) sequencer.

\subsubsection{Statistical analysis}

The genotypic frequencies were calculated and the HardyWeinberg equilibrium (HWE) for each breed were analysed by means of a $\chi 2$ test of PopGene 32 (version 1.31). The traits were compared among the genotypes. Association analyses between the SNPs and traits in 768 quails were evaluated according to two-way analysis with SPSS software (version 


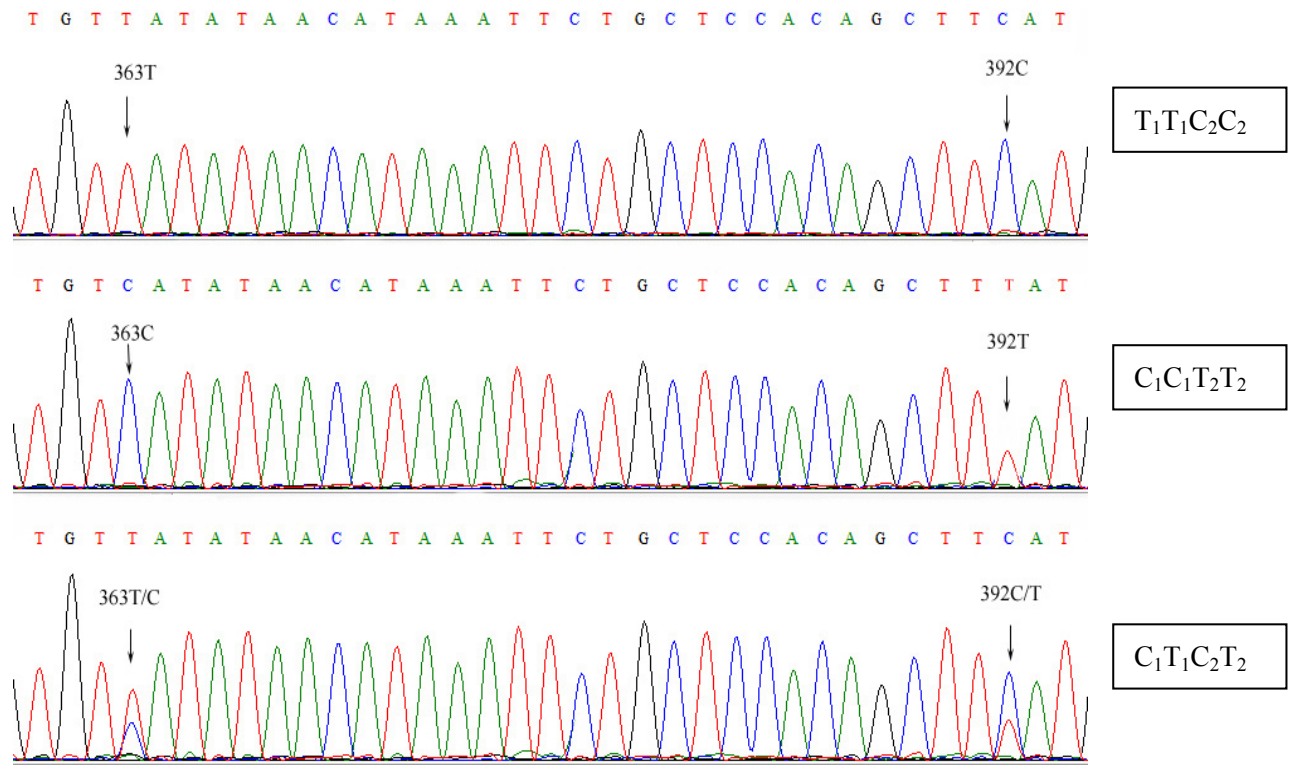

Figure 2. Sequencing results showing the sequence amplified by primer intron 11 of VLDLR gene containing 363T $>\mathrm{C}$ and $392 \mathrm{C}>\mathrm{T}$. The two mutations are linked with each other. $\mathrm{T}_{1} \mathrm{~T}_{1} \mathrm{C}_{2} \mathrm{C}_{2}$ genotype contains two $363 \mathrm{~T}$ and two $392 \mathrm{C}$ single strands $\left(\right.$ allele $\left.\mathrm{T}_{1} \mathrm{C}_{2}\right)$; the $\mathrm{C}_{1} \mathrm{C}_{1} \mathrm{~T}_{2} \mathrm{~T}_{2}$ genotype contains two $363 \mathrm{C}$ and two $392 \mathrm{~T}$ single strands (allele $\mathrm{C}_{1} \mathrm{~T}_{2}$ ); and the $\mathrm{C}_{1} \mathrm{~T}_{1} \mathrm{C}_{2} \mathrm{~T}_{2}$ genotype contains one 363T-392C single strand and one $363 \mathrm{C}-392 \mathrm{~T}$ single strand.

16.0, SPSS Inc., Chicago, IL, USA) using the following equation:

$Y=\mu+G+L+G \times L+e$,

where $Y$ is the dependent variable (analysed traits), $\mu$ is the overall mean, $G$ is the genotype of VLDLR intron $11, L$ is the quail population, $G \times L$ is the interaction between genotype and quail population (which is a fixed effect) and $e$ is the random error.

Difference between genotypes was determined by least squares.

\section{Results}

\subsection{Polymorphism identification and detection}

The sequences amplified with four pairs of primers (P1, P2, P3 and P4 for exon 5, intron 6,11 and 13 of the VLDLR gene, respectively) were aligned among yellow feather quails and chestnut feather quails. No base variation was found in exon 5, intron 6 and intron 13. There were two novel variation loci in intron $11,363 \mathrm{~T}>\mathrm{C}(\mathrm{T} \rightarrow \mathrm{C}$ variation at position $363)$ and $392 \mathrm{C}>\mathrm{T}(\mathrm{C} \rightarrow \mathrm{T}$ variation at position 392). In these two SNP loci, only 392C $>\mathrm{T}$ locus changed the recognition site of restriction endonucleases FatI; therefore, the polymorphism of 392C > T locus can be detected by PCR-RFLP using the amplification product. At this locus, the bands of different genotypes are shown in Fig. 1. Three genotypes were found in this locus for the two quail populations. The comparison among the nucleotide sequences of different geno- types is presented in Fig. 2. The sequencing results showed that when $\mathrm{C}$ appeared at nucleotide position 392 , $\mathrm{T}$ appeared at nucleotide position 363; when $\mathrm{T}$ appeared at nucleotide position 392, C appeared at nucleotide position 363; and when $\mathrm{C}$ and $\mathrm{T}$ appeared at nucleotide position $392, \mathrm{~T}$ and $\mathrm{C}$ appeared at nucleotide position 363 . Thus, we conjectured that the two variations were linked with each other. The genotype with $\mathrm{T}$ at the 363 position and $\mathrm{C}$ at the 392 position was named $T_{1} T_{1} C_{2} C_{2}$, the genotype with $C$ at the 363 position and $\mathrm{T}$ at the 39 positions was named $\mathrm{C}_{1} \mathrm{C}_{1} \mathrm{~T}_{2} \mathrm{~T}_{2}$, and the genotype with $\mathrm{T} / \mathrm{C}$ at the 363 position and $\mathrm{C} / \mathrm{T}$ at the 392 position was named $C_{1} T_{1} C_{2} T_{2}$. The sequences having variations in intron 11 were submitted to GenBank (accession numbers: KC977989 for the $\mathrm{T}_{1} \mathrm{~T}_{1} \mathrm{C}_{2} \mathrm{C}_{2}$ genotype and KC977990 for the $\mathrm{C}_{1} \mathrm{C}_{1} \mathrm{~T}_{2} \mathrm{~T}_{2}$ genotype).

\subsection{Allele and genotype distribution of VLDLR gene intron 11}

Allele and genotype frequencies of VLDLR gene intron 11 in the two quail populations are listed in Table 2. The results indicated that, at the two linkage loci, T1C2 allele was the preponderant allele in yellow feather and chestnut feather quail. The yellow feather and chestnut feather quail populations all deviated from the HWE $(P<0.01)$. 
Table 2. Allele and genotype frequencies at intron 11 locus of VLDLR gene in two quail populations.

\begin{tabular}{lllll|ll|l}
\hline \multirow{2}{*}{ Breeds } & \multirow{2}{*}{ Number } & \multicolumn{3}{c}{ Genotype frequencies } & Gene frequencies & $\chi^{2}(\mathrm{HWE})$ \\
\cline { 3 - 8 } & & $\mathrm{T}_{1} \mathrm{~T}_{1} \mathrm{C}_{2} \mathrm{C}_{2}$ & $\mathrm{C}_{1} \mathrm{C}_{1} \mathrm{~T}_{2} \mathrm{~T}_{2}$ & $\mathrm{C}_{1} \mathrm{~T}_{1} \mathrm{C}_{2} \mathrm{~T}_{2}$ & $\mathrm{~T}_{1} \mathrm{C}_{2}$ & $\mathrm{C}_{1} \mathrm{~T}_{2}$ & \\
\hline Yellow feather quail & 384 & 0.6250 & 0.3125 & 0.0625 & 0.6562 & 0.3438 & $36.6730^{* *}$ \\
Chestnut feather quail & 384 & 0.6042 & 0.2708 & 0.1250 & 0.6667 & 0.3333 & $25.6693^{* *}$ \\
\hline
\end{tabular}

$\chi 2$ (HWE): Hardy-Weinberg equilibrium $\chi 2$ value; ${ }^{* *}$ shows that $P<0.01$ and the SNP locus in the population was not at Hardy-Weinberg equilibrium.

Table 3. Least-squares means and standard errors of the laying traits in two quail populations.

\begin{tabular}{|c|c|c|c|c|c|c|}
\hline \multirow[t]{2}{*}{ Traits } & \multicolumn{3}{|c|}{ Yellow feather quail (mean $\pm \mathrm{SE}$ ) } & \multicolumn{3}{|c|}{ Chestnut feather quail (mean $\pm \mathrm{SE}$ ) } \\
\hline & $\mathrm{T}_{1} \mathrm{~T}_{1} \mathrm{C}_{2} \mathrm{C}_{2}(n=240)$ & $\mathrm{C}_{1} \mathrm{C}_{1} \mathrm{~T}_{2} \mathrm{~T}_{2}(n=120)$ & $\mathrm{C}_{1} \mathrm{~T}_{1} \mathrm{C}_{2} \mathrm{~T}_{2}(n=24)$ & $\mathrm{T}_{1} \mathrm{~T}_{1} \mathrm{C}_{2} \mathrm{C}_{2}(n=232)$ & $\mathrm{C}_{1} \mathrm{C}_{1} \mathrm{~T}_{2} \mathrm{~T}_{2}(n=104)$ & $\mathrm{C}_{1} \mathrm{~T}_{1} \mathrm{C}_{2} \mathrm{~T}_{2}(n=48)$ \\
\hline Weight of first egg $(\mathrm{g})$ & $140.07 \pm 1.46^{\mathrm{b}}$ & $142.87 \pm 2.81^{\mathrm{ab}}$ & $149.33 \pm 1.45^{\mathrm{a}}$ & $141.72 \pm 1.94^{\mathrm{a}}$ & $136.31 \pm 3.33^{\mathrm{ab}}$ & $128.67 \pm 3.19^{\mathrm{b}}$ \\
\hline Age of first egg (d) & $44.93 \pm 0.53^{\mathrm{b}}$ & $45.07 \pm 0.64^{\mathrm{ab}}$ & $48.33 \pm 0.68^{\mathrm{a}}$ & $47.24 \pm 0.71^{\mathrm{a}}$ & $45.69 \pm 1.11^{\mathrm{b}}$ & $47.83 \pm 1.68^{\mathrm{ab}}$ \\
\hline Egg weight (g) & $9.63 \pm 0.19$ & $8.87 \pm 0.24$ & $10.27 \pm 0.16$ & $11.06 \pm 0.19$ & $10.26 \pm 0.15$ & $10.73 \pm 0.0 .15$ \\
\hline Weight of 20 -week (g) & $153.10 \pm 2.21$ & $147.47 \pm 3.48$ & $155.00 \pm 2.99$ & $160.41 \pm 2.49^{\mathrm{a}}$ & $150.69 \pm 2.52^{b}$ & $153.50 \pm 3.81^{\mathrm{ab}}$ \\
\hline Egg number of 20-week & $86.50 \pm 0.97^{\mathrm{a}}$ & $85.07 \pm 1.37^{\mathrm{a}}$ & $77.00 \pm 2.05^{\mathrm{b}}$ & $79.79 \pm 1.41^{\mathrm{b}}$ & $86.00 \pm 2.15^{\mathrm{a}}$ & $73.33 \pm 2.33^{\mathrm{b}}$ \\
\hline
\end{tabular}

Different superscript letters (a, b and c) were significantly different (LSD test, $P<0.05$ ) in genotypes $\mathrm{T}_{1} \mathrm{~T}_{1} \mathrm{C}_{2} \mathrm{C}_{2}, \mathrm{C}_{1} \mathrm{C}_{1} \mathrm{~T}_{2} \mathrm{~T}_{2}$ and $\mathrm{C}_{1} \mathrm{~T}_{1} \mathrm{C}_{2} \mathrm{~T}_{2} ; n$ is the number of genotypes in the population.

Table 4. Effects ( $P$ value) of polymorphism of VLDLR gene intron 11 on quail laying traits.

\begin{tabular}{lccc}
\hline Traits & Genotype & population & $\begin{array}{c}\text { Genotype } \times \\
\text { Population }\end{array}$ \\
\hline Weight of first egg $(\mathrm{g})$ & 0.011 & 0.002 & 0.640 \\
Age of first egg (d) & 0.017 & 0.0426 & 0.420 \\
Egg weight (g) & 0.027 & 0.008 & 0.845 \\
Weight of 20-week (g) & 0.030 & 0.038 & 0.554 \\
Egg number of 20-week & 0.001 & 0.014 & 0.115 \\
\hline
\end{tabular}

\subsection{Association of polymorphisms with laying traits at VLDLR gene intron 11}

The association analysis revealed that, at the two linkage loci, in the yellow feather quail population, the quails with $\mathrm{C}_{1} \mathrm{~T}_{1} \mathrm{C}_{2} \mathrm{~T}_{2}$ genotypes had higher weight and age of first egg than those with $\mathrm{T}_{1} \mathrm{~T}_{1} \mathrm{C}_{2} \mathrm{C}_{2}$ genotypes $(P<0.05)$, and the quails with homozygotes $\left(\mathrm{T}_{1} \mathrm{~T}_{1} \mathrm{C}_{2} \mathrm{C}_{2}\right.$ and $\mathrm{C}_{1} \mathrm{C}_{1} \mathrm{~T}_{2} \mathrm{~T}_{2}$ genotypes) had higher egg number of 20 -week-old than those with heterozygotes $\left(\mathrm{C}_{1} \mathrm{~T}_{1} \mathrm{C}_{2} \mathrm{~T}_{2}\right.$ genotype $)(P<0.05)$. In the chestnut feather quail, the quails with $\mathrm{T}_{1} \mathrm{~T}_{1} \mathrm{C}_{2} \mathrm{C}_{2}$ genotype had higher age of first egg and weight of 20 -week than those with $\mathrm{C}_{1} \mathrm{C}_{1} \mathrm{~T}_{2} \mathrm{~T}_{2}$ genotype $(P<0.05)$, and the quails with $\mathrm{T}_{1} \mathrm{~T}_{1} \mathrm{C}_{2} \mathrm{C}_{2}$ genotype had higher weight of first egg than those with $\mathrm{C}_{1} \mathrm{~T}_{1} \mathrm{C}_{2} \mathrm{~T}_{2}$ genotype $(P<0.05)$. In addition, the $\mathrm{C}_{1} \mathrm{C}_{1} \mathrm{~T}_{2} \mathrm{~T}_{2}$ genotype had higher egg number of 20-weekold than those with $\mathrm{T}_{1} \mathrm{~T}_{1} \mathrm{C}_{2} \mathrm{C}_{2}$ and $\mathrm{C}_{1} \mathrm{~T}_{1} \mathrm{C}_{2} \mathrm{~T}_{2}$ genotypes $(P<0.05)$ (Table 3). Furthermore, no significant associations of genotypes with other traits were detected $(P>0.05)$.

\subsection{Interaction between the VLDLR gene intron 11 and genetic background of the two quail populations}

The analyses of the interaction between the intron 11 genotypes of VLDLR gene and the genetic background of the two quail populations are listed in Table 4. For the weight of first egg, the age of first egg, egg weight, the weight of 20 -week and the egg number of 20-week, the results showed that the effects ( $P$ values) for the interaction effects between genotypes or populations and laying traits were all less than 0.05 and showed significant differences. However, the $P$ values for the interaction effects between the genotypes and populations had no significant differences $(P>0.05)$.

\section{Discussion}

In the present study, the results showed that VLDLR gene intron 11 loci for the yellow feather and the chestnut feather quail populations deviated from the HWE $(P<0.01)$. One explanation could be that they suffered intensive selection for the commercial purpose. In selected populations, deviations of genotype frequencies from the HWE should be expected for loci with impact on traits under selection (Goliášová and Wolf, 2004).

The candidate gene approach is a powerful method to investigate associations of gene polymorphisms with economically important traits in farm animals (Rothschild and Soller, 1997). The SNPs are widely used in linkage analyses and for the evaluation of variability in natural populations because of their robustness in laboratory handling and data interpretation (An et al., 2011). Genetic variation in traits of interest is the basis for future breeding programs. The variation is displayed by genetic differences between individuals, families and populations within a given species (Groeneveld et al., 
2010). Many studies reported that the VLDLR gene was associated with reproduction in oviparous species (Agulleiro et al., 2007; Han et al., 2009; Wang et al., 2011; Roth and Khalaila, 2012; Mizuta et al., 2013). In this study, the VLDLR gene was selected as a candidate gene to investigate associations of gene polymorphisms with some laying traits in two quail populations. The PCR-RFLP results indicated that intron 11 of the VLDLR gene showed polymorphism patterns in the two quail populations. Comparisons among sequencing results showed that there were two linkage variations in intron $11(363 \mathrm{~T}>\mathrm{C}, 392 \mathrm{C}>\mathrm{T})$. The two linkage variations were strongly associated with the weight of first egg, age of first egg and the egg number of 20 -week-old in both populations. This result was similar to previous reports for chickens (Zhan et al., 2009; Cao et al., 2012). The alteration in the intron as well as the silent mutation in coding regions was useful for the evaluation of the association with production traits (Dybus and Grzesiak, 2006; Jędrzejczak et al., 2006). The two alterations of VLDLR gene intron 11 may be linked with another alteration in the VLDLR gene which results in an amino acid alteration. Based on the results obtained from this research, it can be inferred that a variation in intron 11 of the VLDLR gene has an effect on laying traits in both quail populations. However, more individuals should be tested in order to validate these associations.

In addition, our population design provided an opportunity to detect the interaction between the VLDLR gene and the genetic background of two quail populations for laying traits. The phenotypic differences between the two populations probably reflect their different genetic backgrounds (the yellow feather quail has higher egg weight; the chestnut feather quail has higher egg number). Interactions between the VLDLR gene and the genetic background were detected because of the associations between the genotypes and laying traits in both quail populations; this illustrates the importance of defining gene effects in specific populations for future applications such as marker-assisted selection.

Acknowledgements. This paper was supported by the Natural Science Foundation for Young Scholars of Hubei Academy of Agricultural Sciences (grant no. 2012NKYJJ11) and the open project of Hubei Key Laboratory of Animal Embryo and Molecular Breeding (grant no. 2015ZD146).

Edited by: K. Wimmers

Reviewed by: two anonymous referees

\section{References}

Agulleiro, M. J., André, M., Morais, S., Cerdà, J., and Babin, P. J.: High Transcript Level of Fatty Acid-Binding Protein 11 but Not of Very Low-Density Lipoprotein Receptor Is Correlated to Ovarian Follicle Atresia in a Teleost Fish (Solea senegalensis), Biol. Reprod., 77, 504-516, 2007.
An, X. P., Hou, J. X., Li, G., Song, Y. X., Wang, J. G., Chen, Q. J., Cui, Y. H., Wang, Y. F., and Cao, B. Y.: Polymorphism identification in the goat KITLG gene and association analysis with litter size, Anim. Genet., 43, 104-107, 2011.

Barber, D. L., Sanders, E. J., Aebersold, R., and Schneider, W. J.: The receptor for yolk lipoprotein deposition in the chicken oocyte, J. Biol. Chem., 266, 18761-18770, 1991.

Bujo, H., Hermann, M., Kaderli, M. O., Jacobsen, L., Sugawara, S., Nimpf, J., Yamamoto, T., and Schneider, W. J.: Chicken oocyte growth is mediated by an eight ligand binding repeat member of the LDL receptor family, EMBO J., 13, 5165-5175, 1994.

Bujo, H., Yamamoto, T., Hayashi, K., Hermann, M., Nimpf, J., and Schneider, W. J.: Mutant oocytic low density lipoprotein receptor gene family member causes atherosclerosis and female sterility, P. Natl. Acad. Sci. USA, 92, 9905-9909, 1995.

Bujo, H., Elkin, R. G., Lindstedt, K. A., Nimpf, J., Bitgood, J. J., and Schneider, W. J.: A Rapid, Polymerase Chain Reaction-Based Procedure for Identifying Mutant Restricted Ovulator Chickens, Poult. Sci., 75, 1113-1117, 1996.

Cao, D. G., Zhou, Y., Lei, Q. X., Han, H. X., Li, F. W., Li, G. M., Lu, Y., Wu, B., and Wang, Z. L.: Associations of Very Low Density Lipoprotein Receptor (VLDLR) Gene Polymorphisms with Reproductive Traits in a Chinese Indigenous Chicken Breed, J. Anim. Vet. Adv., 11, 3662-3667, 2012.

Dybus, A. and Grzesiak, W.: GHRH/HaeIII gene polymorphism and its associations with milk production traits in Polish Black-andWhite cattle, Arch. Tierz., 49, 434-438, 2006.

Groeneveld, L. F., Lenstra, J. A., Eding, H., Toro, M. A., Scherf, B., Pilling, D., Negrini, R., Finlay, E. K., Jianlin, H., Groeneveld, E., Weigend, S., and GLOBALDIV Consortium: Genetic diversity in farm animals - a review, Anim. Genet., 41 (Suppl.), 6-31, 2010.

Goliášová, E. and Wolf, J.: Impact of the ESR gene on litter size and production traits in Czech Large White pigs, Anim. Genet., 35, 293-297, 2004.

Han, D., Haunerland, N. H., and Williams, T. D.: Variation in yolk precursor receptor mRNA expression is a key determinant of reproductive phenotype in the zebra finch (Taeniopygia guttata), J. Exp. Biol., 212, 1277-1283, 2009.

Jędrzejczak, M., Szatkowska, I., Zych, S., Grzesiak, W., Czerniawska-Piątkowska, E., and Dybus, A.: Evaluation of associations of the polymorphism in the placenta specific promoter 1.1 of the CYP19 gene in Black-and-White and Jersey cattle with milk production traits, Arch. Tierz., 49, 311-314, 2006.

Mizuta, H., Luo, W., Ito, Y., Mushirobira, Y., Todo, T., Hara, A., Reading, B. J., Sullivan, C. V., and Hiramatsu, N.: Ovarian expression and localization of a vitellogenin receptor with eight ligand binding repeats in the cutthroat trout (Oncorhynchus clarki), Comp. Biochem. Phys. B, 166, 81-90, 2013.

Nimpf, J., Radosavljevic, M. J., and Schneider, W. J.: Oocytes from the mutant restricted ovulator hen lack receptor for very low density lipoprotein, J. Biol. Chem., 264, 1393-1398, 1989.

Nimpf, J. and Schneider, W. J.: Receptor-mediated lipoprotein transport in laying hen, J. Nutr., 121, 1471-1474, 1991.

Roth, Z. and Khalaila, I.: Identification and characterization of the vitellogenin receptor in Macrobrachium rosenbergii and its expression during vitellogenesis, Mol. Reprod. Dev., 79, 478-487, 2012. 
Rothschild, M. F. and Soller, M.: Candidate gene analysis to detect genes controlling traits of economic importance in domestic livestock, Probe, 8, 13-20, 1997.

Schneider, W. J., Nimpf, J., Brandes, C., and Drexler, M.: The lowdensity lipoprotein receptor family: Genetics, function, and evolution, Curr. Ather. Rep., 1, 115-122, 1999.

Schneider, W. J. and Nimpf, J.: LDL receptor relatives at the crossroad of endocytosis and signaling, Cell Mol. Life Sci., 60, 892903, 2003.

Shen, X., Steyrer, E., Retzek, H., Sanders, E. J., and Schneider, W. J.: Chicken oocyte growth: receptor-mediated yolk deposition, Cell Tissue Res., 272, 459-471, 1993.
Wang, C., Li, S. J., Yu, W. H., Xin, Q. W., Li, C., Feng, Y. P., Peng, X. L., and Gong, Y. Z.: Cloning and expression profiling of the $V L D L R$ gene associated with egg performance in duck (Anas platyrhynchos), Genet. Sel. Evol., 43, 29, doi:10.1186/12979686-43-29, 2011.

Zhan, H. Q., Feng, Y. P., Shen, S. X., Gong, P., Peng, X. L., Li, S. J., and Gong, Y. Z.: Polymorphism of Chicken Occyte Vitellogenesis Receptor Gene (OVR) and Association with Egg Traits of Chickens, J. Agric. Biotechnol., 17, 967-971, 2009. 